\title{
Arid Agroecosystem Shrubs Enhance Enzyme Activities during the Dry Season
}

\author{
Sire Diedhiou1,2*, Komi B. Assigbetsee3, Arfang 0. K. Goudiaby1, Ibrahima Diedhiou4, \\ Aminata N. Badiane ${ }^{5}$, Modou Sène ${ }^{5}$, Mamadou Khouma5, Arona N. S. Samba5, Richard P. Dick ${ }^{6}$ \\ ${ }^{1}$ Agroforestry Department, Assane Seck University, Ziguinchor, Senegal \\ ${ }^{2}$ Crop and Soil Sciences Department, Oregon State University, Corvallis, OR, USA \\ ${ }^{3}$ French Research Institute for Development (IRD), Dakar, Senegal \\ ${ }^{4}$ National School of Agriculture, Thies University, Thies, Senegal \\ ${ }^{5}$ Senegalese Agricultural Research Institute (ISRA), Dakar, Senegal \\ ${ }^{6}$ School of Natural Ressources, Ohio State University, Columbus, OH, USA \\ Email: *sdiedhiou@univ-zig.sn
}

How to cite this paper: Diedhiou, S., Assigbetsee, K.B., Goudiaby, A.O.K., Diedhiou, I., Badiane, A.N., Sène, M., Khouma, M., Samba, A.N.S. and Dick, R.P. (2020) Arid Agroecosystem Shrubs Enhance Enzyme Activities during the Dry Season. American Journal of Plant Sciences, 11, 180-188.

https://doi.org/10.4236/ajps.2020.112014

Received: January 6, 2020

Accepted: February 17, 2020

Published: February 20, 2020

Copyright $\odot 2020$ by author(s) and Scientific Research Publishing Inc. This work is licensed under the Creative Commons Attribution International License (CC BY 4.0).

http://creativecommons.org/licenses/by/4.0/

\begin{abstract}
In Senegal, in the Sahel region, the agroecosystem is dominated by two Sahelian shrubs able to redistribute water from deep soil to the surface. This study was carried out to determine the impact of these shrubs on soil microbial activity. A $2 \times 3$ factorial design was set up during the dry and wet season with three soil treatments: rhizospheric, bulk and non-rhizospheric soil. During the dry season, the presence of shrubs resulted in significantly higher phosphatase acid activity for Guiera senegalensis $(p<0.001)$, respectively, $717 \mu \mathrm{g}$ $\mathrm{pNP} / \mathrm{h} / \mathrm{g}$ of dry soil in the rhizosphere soil, $333 \mu \mathrm{g} \mathrm{pNP} / \mathrm{h} / \mathrm{g}$ in the bulk soil and $193 \mu \mathrm{g} \mathrm{pNP} / \mathrm{h} / \mathrm{g}$ in the non-rhizosphere soil. The same trend was observed for all other enzyme activities and $\mathrm{MBC}$ during both seasons except for mineral N. Mineral N was not statistically different between the rhizospheric and bulk soil during the dry season. $\beta$-glucosidase and phosphatase acid had the highest correlation with the rhizospheric soil during the dry season respectively $98 \%$ and $97 \%$. Soil moisture content was highly correlated with the rhizospheric soil (85\%), chitinase activity (99\%) and $\beta$-glucosidase (97\%). Shrubs maintained a moister environment during the dry season which was critical in stimulating microbial activities; this has significant implications for agroecosystem management in the Sahel.
\end{abstract}

\section{Keywords}

Shrubs, Sahel, Hydraulic Lift, Enzyme Activities, Rhizosphere

\section{Introduction}

In Semi-arid Senegal, two shrubs species dominate in farmers' field Guiera 
senegalensis and Piliostigma reticulatum. Although coppiced and burnt during each cropping season, the shrubs regrow during the long dry season. Previous recommendations of massive uprooting of shrubs were based on the fear that shrubs may be competitive and reduce crop yield [1]. However, in a preliminary study in Niger in farmers' fields, [2] showed that millet growing within the influence of $G$. senegalensis rhizosphere had more significant growth than when grown outside the influence of the shrub. [3] showed an increase in peanut and millet yield by over $50 \%$ during 3 cropping seasons when $G$. senegalensis and $P$. reticulatum are allowed to grow in the field. The presence of shrubs all year round may drive biogeochemical processes and maintain microbial communities through root exudates [4]. The composition of plant exudates are very specific and vary with plant species or the environment [5]. [6] made an important discovery for G. senegalensis and P. reticulatum; the authors found that the roots of the shrub redistribute water from the subsoil to the surface. The amount of water redistributed can go as high as $0.1 \mathrm{~mm}$ per day for $P$. reticulatum and $0.2 \mathrm{~mm}$ per day for G. senegalensis [6]. Hydraulic redistribution is characteristic of semi-arid to arid environments during periods of drought [7] [8]. Water redistribution could be essential to maintain microbial communities and drive biogeochemical processes during the long dry season. Few studies have been done to determine how shrubs hydraulic lift would affect microbial activities in semi-arid areas. Therefore, the objective of this study was to assess soil microbial activities of shrubs rhizosphere during the wet and dry season. We hypothesized that the shrubs would maintain a moist environment around roots that would sustain soil microbial activity, especially during the long period of drought. To test this hypothesis, we used a combination of enzyme activities, microbial biomass carbon $(\mathrm{MBC})$ and mineral $\mathrm{N}$.

\section{Material and Methods}

\subsection{Experimental Site and Design}

The study was conducted in farmers' field located in two agro-ecological sites of Senegal with a mean annual temperature of $32^{\circ} \mathrm{C}$ and a water table of approximately 8 to $10 \mathrm{~m}$ characterized by 9 months of dry season (Figure 1). At the first site, G. senegalensis is predominant on a sandy, ferruginous arid soil [9], with a lower rainfall around $300 \mathrm{~mm}$ per year. In the second site, $P$. reticulatum predominates in loamy-sandy soil with rainfall of $700 \mathrm{~mm}$ per year. The experimental design was a $2 \times 3$ factorial design setup during the dry and wet season with three soil treatments: rhizospheric soil, bulk soil (between roots) and non-rhizospheric soil (soil sampled two meters away from the shrub. Soil samples were collected in the first $0-10 \mathrm{~cm}$ depth during the dry season, March 2005, and the wet season, August 2005. In each experimental site, soils were sampled randomly following the fourth direction (East, West, North, and South) under twelve plants. Thus, for each plant, there were 4 samples in the rhizospheric zone, 4 samples in the bulk zone and 4 samples in the non-rhizospheric 


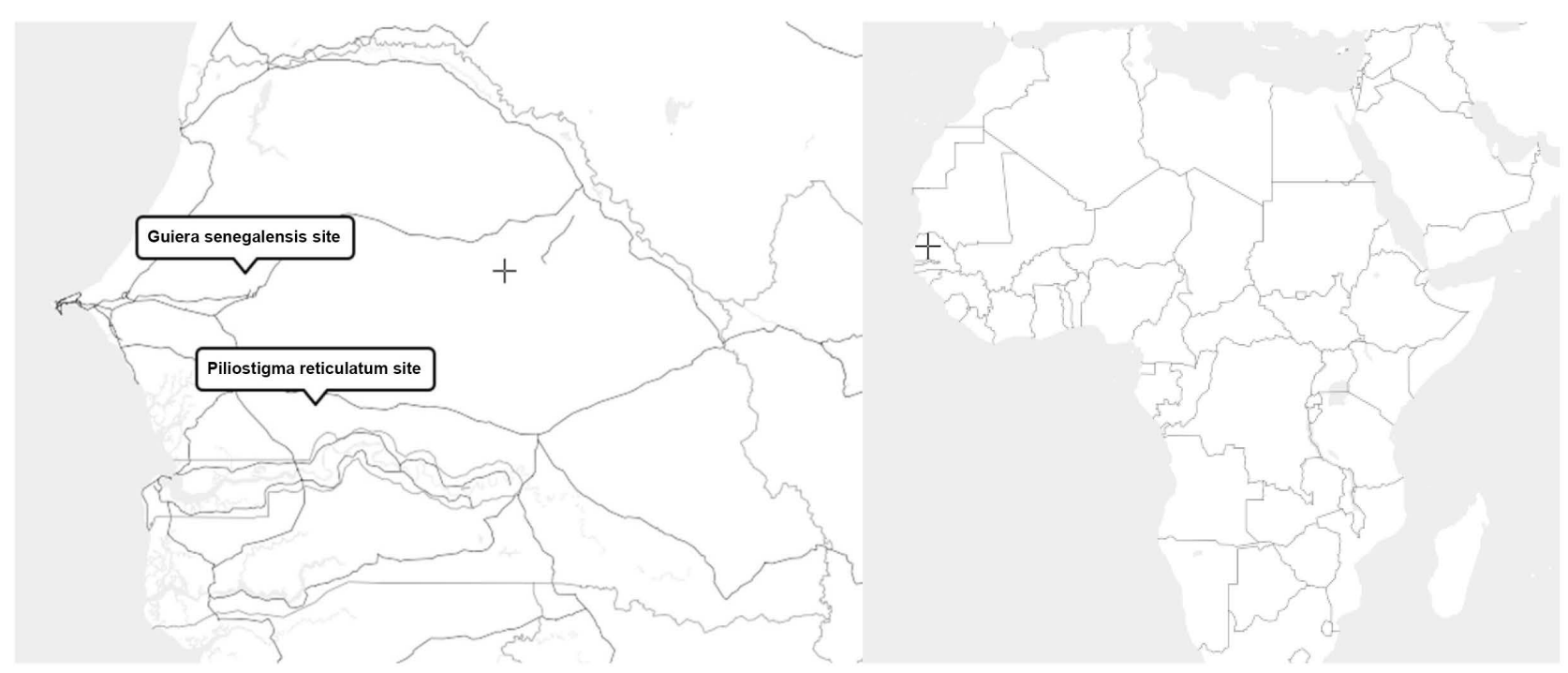

Figure 1. Study sites localisation for Guiera senegalensis and Piliostigma reticulatum.

area. Sixteen (16) soil samples from 4 shrubs were then mixed, which resulted in 3 replicates each for the rhizospheric soil, the bulk soil and the non-rhizospheric soil. Samples were homogenized and then crushed to pass through a $2 \mathrm{~mm}$ mesh screen, maintained at field moisture and stored at $4^{\circ} \mathrm{C}$ until analyzed.

\subsection{Enzyme Activities}

Enzyme assays were completed within one week of sampling. Phosphatase acid, $\beta$-glucosidase, chitinase, and urease activities were measured. Those enzymes are related to biogeochemical cycles of phosphorus, carbon ( $\beta$-glucosidase, chitinase) and nitrogen, respectively. Chitinase is characteristic of fungi activities. An original method described by [10] and modified by [11] was used to assess $\beta$-glucosidase and chitinase activities. A triplicate of $100 \mathrm{mg}$ of fresh soil from each sample was incubated for 2 hours at $37^{\circ} \mathrm{C}$. Before incubation, $100 \mu \mathrm{l}$ of $5 \mathrm{mM}$ para-nitrophenyl $\beta$-d-glucopyranoside (pNP) was added as the substrate for $\beta$-glucosidase and $100 \mu \mathrm{l}$ of $5 \mathrm{mM}$ of paranitrophenyl $N$-acetyl glucosaminide ( $5 \mathrm{mM}$, Sigma) as the substrate for chitinase. Citrate-phosphate, pH 5.8 [12] was used to buffer the mixture, and pNP was measured 15 min after stopping the reaction at $400 \mathrm{~nm}$. Results were expressed as $\mu \mathrm{g} \mathrm{pNP}$ released $\mathrm{g}^{-1} \cdot \mathrm{h}^{-1}$. For the phosphatase activity, the method by [13] was used with the same principle as previous enzymes. The pNP phosphate was quantified at $420 \mathrm{~nm}$. The urease activity was measured using $1 \mathrm{~g}$ of soil incubated with urea as a substrate [14]. The ammonium was quantified with a spectrophotometer set at $660 \mathrm{~nm}$.

\subsection{Microbial Biomass Carbon (MBC) and Mineral N}

A modified method by [15] was used to quantify $\mathrm{MBC}$ by chloroform-fumigation extraction (CFE). A subsample of $10 \mathrm{~g}$ of moist soil was fumigated with chloroform (ethanol free) and then incubated for 10 days. Then, a $2 \mathrm{M} \mathrm{KCl}$ solution was mixed with fumigated and unfumigated control samples for $60 \mathrm{~min}$ on a ro- 
tator shaker. After filtration, $2 \mathrm{ml}$ were mixed with $0.5 \mathrm{ml}$ of $0.4 \mathrm{M}$ sodium citrate solution. The Ninhydrin-reactive $\mathrm{N}$ was quantified by colorimetry at an optical density (OD) of $750 \mathrm{~nm}$ [16]. The difference in ninhydrin-reactive $\mathrm{N}$ was then estimated by multiplication with 21 to determine MBC, which is expressed as $\mu \mathrm{g} \mathrm{C} / \mathrm{g}$ of dry soil. Soil inorganic-N was quantified in the same extract $(2 \mathrm{M} \mathrm{KCl})$ using the method by [17]. Ammonium was quantified at an OD of $660 \mathrm{~nm}$ and nitrate at an OD of $525 \mathrm{~nm}$. Inorganic nitrogen was computed as the sum of ammonium and nitrate and the results expressed as $\mu \mathrm{g} \cdot \mathrm{N} \cdot \mathrm{g}^{-1}$ of dry soil.

\subsection{Statistical Analysis}

The software SAS software was used to analyze the data [18]. Enzyme activities, MBC and mineral N, were assessed using ANOVA. Mean values were compared using Tukey' HSD test (honestly significant difference) at a significance of $p<$ 0.05. Data were further analyzed using principal component analysis (PCA), and a correlation matrix of different parameters was established.

\section{Results and Discussion}

\subsection{Enzyme Activities, MBC and Mineral N}

Phosphatase acid activity for $G$. senegalensis was significantly higher $(p<0.001)$ in the rhizosphere soil ( $1145 \mu \mathrm{g} \mathrm{pNP} / \mathrm{h} / \mathrm{g}$ of dry soil) compared to the bulk soil (590 $\mu \mathrm{g} \mathrm{pNP/h/g}$ of dry soil)and the non-rhizosphere soil (502 $\mu \mathrm{g} \mathrm{pNP/h/g}$ of dry soil) during the wet season. The same trend was also observed during the dry season but with much lower values for both shrubs (Figure 2 and Figure 3 ).

Activities of $\beta$-glucosidase and chitinase were also statistically higher $(p<$ 0.001 ) in the rhizospheric soil than in the bulk and non-rhizospheric soil for both seasons (Figure 1 and Figure 2). The non-rhizospheric soil had the lowest enzyme activities except for the chitinase during the dry season where the activity was the same for the bulk and the non-rhizospheric soil. The rhizospheric soil has been shown to have higher microbial densities than the bulk soil [19] [20]. The complex mixture of organic compounds from root exudates provides a source of reduced carbon, nitrogen, and other nutrients which favor a productive environment [21]. This environment promotes higher microbial activity, higher MBC and more diverse communities [22]. Phosphatase and $\beta$-glucosidase were sensitive to the nutrient status of the soil and plant availability of soluble carbon and phosphorus. This corroborates previous studies by [23] and [3] who found that decomposition rate of shrubs litter as well as soil nutrient processes were enhanced in the rhizosphere of Sahelian shrubs. For the chitinase activity, during the dry season, the lack of water probably limited fungal growth and may explain why there were no differences between the non-rhizospheric and the bulk soil.

Urease activity was significantly higher in rhizospheric soil than in bulk and non-rhizospheric soil during the dry season (Table $1 ; p<0001$ ). During the wet 


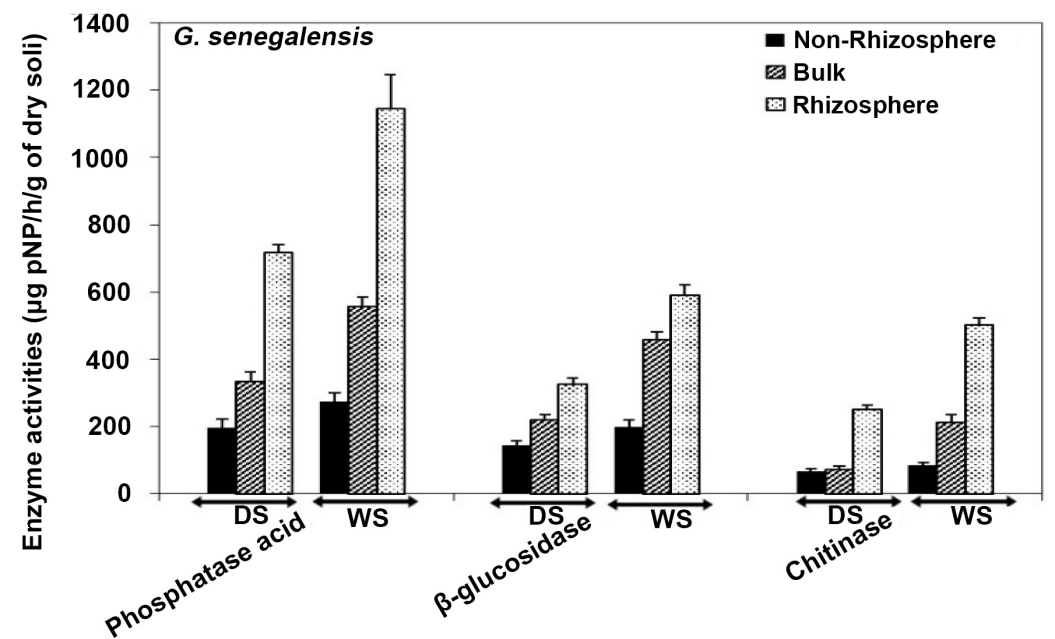

Figure 2. Activities of phosphatase acid, $\beta$-glucosidase and chitinase from soil sampled under $G$. senegalensis during the dry (DS) and wet season (WS). Barres are standards of error.

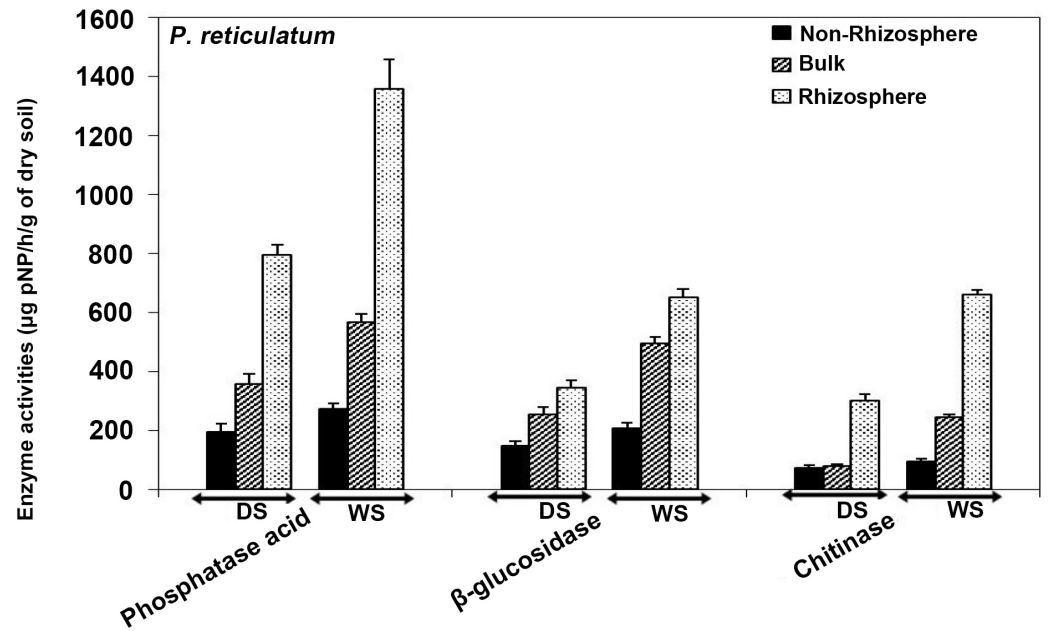

Figure 3. Activities of phosphatase acid, $\beta$-glucosidase and chitinase from soil sampled under $P$. reticulatum during the dry (DS) and wet season (WS). Barres are standards of error.

season, however, this activity was the same in the bulk and rhizospheric soil ( $p>$ $0.05)$, but significantly higher than the non-rhizospheric soil $(p<0.001)$. However, the lack of difference between the bulk and rhizospheric soil for the urease activity may be due to the fact that the soil is moister and more exudates are available which may allow translocation of nutrients from rhizospheric soil to bulk since there is no physical separation.

MBC was significantly higher $(p<0.01)$ in rhizospheric soil than in non-rhizospheric soil and during the wet season as opposed to the dry season for both species (Table 1). Mineral $\mathrm{N}$ remained at the same value for the rhizospheric and bulk soil $(p<0.05)$; however, this value was statistically higher during the wet season than during the dry season. During the wet season, plants usually have more nutrients available and would be expected to liberate more exudates, 
Table 1. Urease activity, MBC, mineral $\mathrm{N}$ and moisture content from soil associated with $G$. senegalensis and $P$. reticulatum during the dry and wet season.

\begin{tabular}{|c|c|c|c|c|c|}
\hline \multirow{2}{*}{ Treatment } & \multicolumn{2}{|r|}{ Urease } & \multirow{2}{*}{$\begin{array}{l}\mathrm{MBC} \\
(\mu \mathrm{g} \mathrm{C})\end{array}$} & \multirow{2}{*}{$\begin{array}{c}\text { Mineral N } \\
(\mu \mathrm{g} N)\end{array}$} & \multirow{2}{*}{$\begin{array}{c}\text { Moisture content } \\
(\%)\end{array}$} \\
\hline & $(\mu \mathrm{g}$ & $\left.\mathrm{NH}_{4}^{+}-\mathrm{N} / \mathrm{h}\right)$ & & & \\
\hline \multicolumn{6}{|c|}{ Guiera senegalensis } \\
\hline \multicolumn{6}{|c|}{ Dry season } \\
\hline Non-rhizosphere & & $1.0^{\mathrm{a}^{*}}$ & $7.3^{\mathrm{a}}$ & $6.7^{\mathrm{a}}$ & $0.5^{\mathrm{a}}$ \\
\hline Bulk & & $2.4^{\star * \mathrm{~b}}$ & $25.6^{\mathrm{c}}$ & $12.1^{\mathrm{c}}$ & $1.0^{\mathrm{b}}$ \\
\hline Rhizosphere & & $4.7^{\mathrm{c}}$ & $38.1^{\mathrm{de}}$ & $14.6^{\mathrm{cd}}$ & $2.6^{\mathrm{c}}$ \\
\hline \multicolumn{6}{|c|}{ Wet season } \\
\hline Non-rhizosphere & & $3.1^{\mathrm{bc}}$ & $12.3^{\mathrm{b}}$ & $8.5^{\mathrm{b}}$ & $5.1^{\mathrm{d}}$ \\
\hline Bulk & & $8.0^{\mathrm{d}}$ & $34.0^{\mathrm{d}}$ & $15.2^{\mathrm{d}}$ & $6.5^{\mathrm{e}}$ \\
\hline Rhizosphere & & $8.7^{\mathrm{e}}$ & $46.1^{\mathrm{f}}$ & $15.5^{\mathrm{d}}$ & $11.5^{\mathrm{f}}$ \\
\hline \multicolumn{6}{|c|}{ Piliostigma reticulatum } \\
\hline \multicolumn{6}{|c|}{ Dry season } \\
\hline Non-rhizosphere & & $1.0^{\mathrm{a}}$ & $6.5^{\mathrm{a}}$ & $8.1^{\mathrm{a}}$ & $0.5^{\mathrm{a}}$ \\
\hline Bulksoil & & $2.2^{\mathrm{b}}$ & $27.0^{c}$ & $15.1^{\mathrm{b}}$ & $1.5^{\mathrm{b}}$ \\
\hline Rhizosphere & & $6.2^{\mathrm{cd}}$ & $45.1^{\mathrm{e}}$ & $15.8^{\mathrm{b}}$ & $2.4^{\mathrm{c}}$ \\
\hline \multicolumn{6}{|c|}{ Wet season } \\
\hline Non-rhizosphere & & $5.3^{\mathrm{c}}$ & $16.5^{\mathrm{b}}$ & $9.1^{\mathrm{a}}$ & $7.8^{\mathrm{d}}$ \\
\hline Bulksoil & & $9.7^{\mathrm{e}}$ & $37.8^{\mathrm{d}}$ & $16.7^{\mathrm{bc}}$ & $9.1^{\mathrm{e}}$ \\
\hline Rhizosphere & & $9.8^{\mathrm{e}}$ & $49.1^{\mathrm{f}}$ & $17.3^{\mathrm{c}}$ & $11.5^{\mathrm{f}}$ \\
\hline
\end{tabular}

${ }^{*}$ For each species, values followed by the same letter in the same column are not significantly different (SNK Test,$<5 \%)$. ${ }^{*}$ All values are expressed per $\mathrm{g}$ of dry soil.

which should stimulate microorganisms. More exudation by roots would support higher microbial activity and interaction, which makes more $\mathrm{C}$ and dead microorganisms available [5].

\subsection{PCA and Correlation of Different Parameters}

PCA showed that the first axis explained most of the variance with $91 \%$ (Figure 4). Microbial communities were separated depending on the location of the soil sample $(p<0.01)$. Microbial communities from the rhizospheric soil formed a cluster statistically different $(p<0.001)$ from the bulk soil and the non-rhizospheric soil. With regard to the location, samples from the wet season separated from the dry season and separation was also based on shrub species. Although all enzymes were highly correlated with rhizospheric soil during the dry season, $(r>90 \%), \beta$-glucosidase showed the highest correlation (98\%) followed by phosphatase acid (97\%). The moisture content was also highly correlated with the rhizospheric soil (85\%), chitinase activity (99\%) and $\beta$-glucosidase (97\%). 


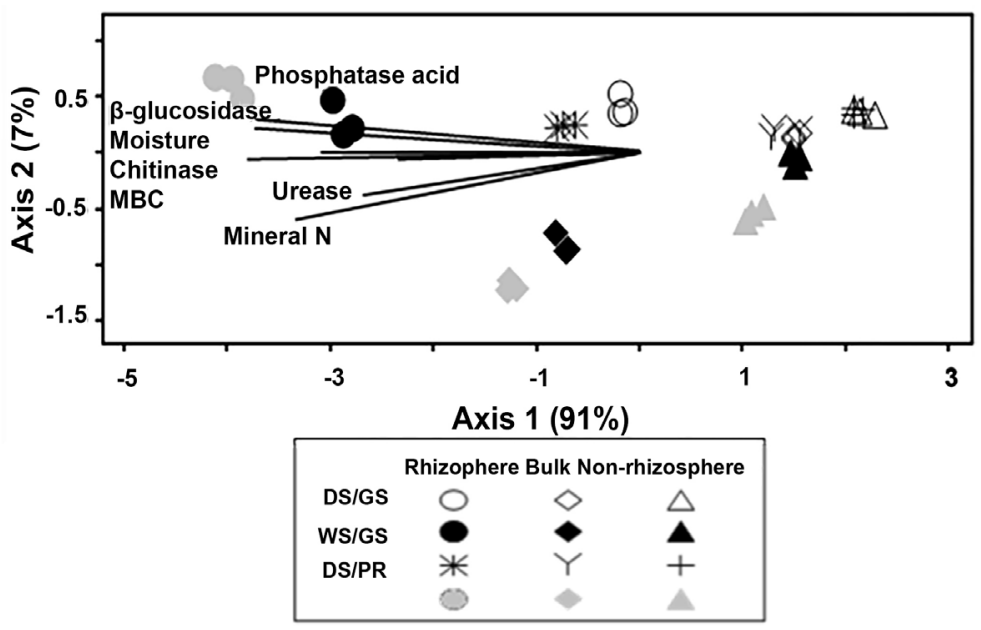

Figure 4. PCA based on four enzyme activities quantified from soil associated with $G$. senegalensis (GS) and $P$. reticulatum (PR) during the dry season (DS) and the wet season (WS). Vectors represent enzyme activities and some soil properties.

P. reticulatum and $G$. senegalensis have been shown to redistribute water from the roots to the subsurface [6]. [24] and [25] showed that hydraulically redistributed water enhanced seedling survival, maintained overstory transpiration during summer drought and had a significant impact on plant drought tolerance and total water utilization. This process may explain high enzyme activities in the shrubs' rhizosphere during the dry season. At some point, the rhizospheric soil would be moister than soil from some distance to the root due to the efflux of water and would impact soil microbial activities. The hydraulic redistribution was critical in supporting soil microorganisms communities which resulted in an increase of enzyme activities, $\mathrm{MBC}$ and mineral $\mathrm{N}$ in the rhizosphere during the dry season.

\section{Conclusion}

Enzyme activities were sensitive with respect to shrubs' rhizosphere and soil moisture. Rhizospheric soil sustained larger, more active communities than did the non-rhizospheric one-presumably by providing elevated levels of $\mathrm{C}$ inputs. Shrubs' influence in soil microbial activities was strong during the wet season as well as during the dry season. Moreover, during the dry season, shrubs maintained a moister environment, which likely was influential in stimulating microbial activities in the rhizospheric soil. Additionally, the maintenance of microbial communities by shrub rhizospheres between wet and dry season suggests hydraulic redistribution of water was critical in supporting microorganisms in the dry season.

\section{Funding}

The National Science Foundation supported this work under Grant No. 0120732. 


\section{Acknowledgements}

The authors are grateful to the Senegalese National Research Institute (ISRA) and the French Research Institute of Development (IRD). This paper is dedicated to late Astou SENE, Mamadou KHOUMA and Samba Arona Ndiaye SAMBA, co-Pis of this work.

\section{Conflicts of Interest}

The authors declare no conflicts of interest regarding the publication of this paper.

\section{References}

[1] Somarriba, E. (1988) Pasture Growth and Floristic Composition under the Shade of Guava (Psidium gujava L.) Trees in Costa Rica. Agroforestry Systems, 6, 153-162. https://doi.org/10.1007/BF02344752

[2] Wezel, A., Rajot, J.L. and Herbrig, C. (2000) Influence of Shrubs on Soil Characteristics and Their Function in Sahelian Agro-Ecosystems in Semi-Arid Niger. Journal of Arid Environments, 44, 383-398. https://doi.org/10.1006/jare.1999.0609

[3] Dossa, E.L., Diedhiou, I., Khouma, M., Sene, M., Badiane, A.N., Samba, S.A.N., Assigbetse, K.B., Sall, S., Lufafa, A., Kizito, F., Dick, R.P. and Saxena, J. (2012) Crop Productivity and Nutrient Dynamics in a Shrub-Based Farming System of the Sahel. Agronomy Journal, 104, 1255-1264. https://doi.org/10.2134/agronj2012.0432

[4] Lynch, J.M. and Whipps, J.M. (1990) Substrate Flow in the Rhizosphere. Plant Soil, 129, 1-10. https://doi.org/10.1007/BF00011685

[5] Sylvia, D.M., Fuhrmann, J.J., Hartel, P.G. and Zoberer, D.A. (2005) Principles and Applications of Soil Microbiology. 3rd Edition, Pearson/Prentice Hall, Upper Saddle River.

[6] Kizito, F., Dragila, M.I., Sene, M., Brooks, J.R., Meinzer, F.C., Diedhiou, I., Diouf, M., Lufafa, A., Dick, R.P., Selker, J. and Cuenca, R. (2012) Hydraulic Redistribution by Two Semi-Arid Shrub Species: Implications for Sahelian Agro-Ecosystems. Journal of Arid Environments, 83, 69-77. https://doi.org/10.1016/j.jaridenv.2012.03.010

[7] Dawson, T.E. (1993) Hydraulic Lift and Water-Use by Plants: Implications for Water-Balance, Performance and Plant Interactions. Oecologia, 95, 565-574. https://doi.org/10.1007/BF00317442

[8] Caldwell, M.M., Dawson, T.E. and Richards, J.H. (1998) Hydraulic Lift: Consequences of Water Efflux from the Roots of Plants. Oecologia, 113, 151-161. https://doi.org/10.1007/s004420050363

[9] FAO (1998) World Reference Base for Soil Resources. Food and Agriculture Organization of the United Nations, Rome. http://www.fao.org/soils-portal/soil-survey/soil-classification/world-reference-base/en

[10] Hayano, K. (1973) A Method for Determination of b-Glucosidase Activity in Soil. Soil Science Plant Nutrition, 19, 103-108. https://doi.org/10.1080/00380768.1973.10432524

[11] Ndour, N.Y.B., Chotte, J.L., Pate, E., Masse, D. and Rouland, C. (2001) Use of Soil Enzyme Activities to Monitor Soil Quality in Natural and Improved Fallows in Semi-Arid Tropical Regions. Applied Soil Ecology, 18, 229-238. https://doi.org/10.1016/S0929-1393(01)00159-7 
[12] Macllvain, T.C. (1921) A Buffer Solution for Colorimetric Comparison. The Journal of Biological Chemistry, 121, 381-390.

[13] Tabatabai, M.A. and Bremner, J.M. (1969) Use of p-Nitrophenyl Phosphate for Assay of Soil Phosphatase Activity. Soil Biology and Biochemistry, 1, 301-307. https://doi.org/10.1016/0038-0717(69)90012-1

[14] Kandeler, E. and Gerber, H. (1988) Short-Term Assay of Soil Urease Activity Using Colorimetric Determination of Ammonium. Biology and Fertility of Soils, 6, 68-72. https://doi.org/10.1007/BF00257924

[15] Amato, M. and Ladd, J.N. (1988) Assay for Microbial Biomass Based on Ninhydrin-Reactive Nitrogen in Extracts of Fumigated Soils. Soil Biology and Biochemistry, 20, 107-114. https://doi.org/10.1016/0038-0717(88)90134-4

[16] Schinner, F., Öhlinger, R., Kandeler, E. and Margesin, R. (1996) Methods in Soil Biology. Springer Verlag, Berlin. https://www.springer.com/gp/book/9783642646331 https://doi.org/10.1007/978-3-642-60966-4

[17] Bremner, J.M. (1965) Nitrogen Availability Indexes. Agronomy, 9, 1324-1345.

[18] SAS Institute, Inc. (1996) SAS/STAT User’s Guide, Version 6.12. Cary.

[19] Semenov, A.M., Bruggen, A.H.C. and Zelenev, V.V. (1999) Moving Waves of Bacterial Populations and Total Organic Carbon along Roots of Wheat. Microbial Ecology, 37, 116-128. https://doi.org/10.1007/s002489900136

[20] Marschner, P., Neumann, G., Kania, A., Weisskopf, L. and Lieberei, R. (2002) Spatial and Temporal Dynamics of Bacterial Community Composition in the Rhizosphere of Cluster Roots of White Lupin (Lupinus albus L.). Plant Soil, 246, 167-174. https://doi.org/10.1023/A:1020663909890

[21] Norton, J.M. and Firestone, M.K. (1991) Carbon Flow in the Rhizosphere of Ponderosa Pine Seedlings. Soil Biology and Biochemistry, 22, 449-455.

https://doi.org/10.1016/0038-0717(90)90177-2

[22] Maloney, P.E., van Bruggen, A.H.C. and Hu, S. (1997) Bacterial Community Structure in Relation to the Carbon Environments in Lettuce and Tomato Rhizospheres and in Bulk Soil. Microbial Ecology, 34, 109-117.

https://doi.org/10.1007/s002489900040

[23] Diedhiou-Sall, S., Dossa, E.L., Diedhiou, I., Badiane, A.N., Assigbetse, K.B., Samba, S.A.N., Khouma, M., Sène, M. and Dick, R.P. (2013) Microbiology and Macrofaunal Activity in Soil beneath Shrub Canopies during Residue Decomposition in Agroecosystems of the Sahel. Soil Science Society of American Journal, 77, 501-511. https://doi.org/10.2136/sssaj2012.0284

[24] Wan, C., Xu, W.W., Sosebee, R.E., Machado, S. and Archer, T. (2000) Hydraulic Lift in Drought-Tolerant and -Susceptible Maize Hybrids. Plant Soil, 219, 117-126. https://doi.org/10.1023/A:1004740511326

[25] Brooks, J.R., Meinzer, C.F., Coulombe, R. and Gregg, J. (2002) Hydraulic Redistribution of Soil Water during Summer Drought in Two Contrasting Pacific Northwest Coniferous Forests. Tree Physiology, 22, 1107-1117.

https://doi.org/10.1093/treephys/22.15-16.1107 